\author{
Jurnal Kumara Cendekia \\ https://jurnal.uns.ac.id/kumara
}

\title{
HUBUNGAN ANTARA PENDAPATAN ORANG TUA TERHADAP PERILAKU PROSOSIAL ANAK USIA DINI DI SEKOLAH
}

\author{
Hesti Wulandari ${ }^{1}$, Yudianto Sujana ${ }^{1}$, Muhammad Munif Syamsuddin ${ }^{1}$ \\ ${ }^{1}$ Program Studi PG-PAUD/ Universitas Sebelas Maret
}

Email: hestiwulandari07@gmail.com, yudianto.sujana@gmail.com, wandamunif@yahoo.com

\begin{abstract}
ABSTRAK
Penelitian ini bertujuan untuk meningkatkan percaya diri anak dengan menerapkan gerak dan lagu di TK Aisyiyah 01 Semanggi Pasar Kliwon Surakarta Tahun Ajaran 2016/2017. Jenis penelitian ini adalah penelitian tindakan kelas(PTK) dengan menggunakan pendekatan kualitatif dan kuantitatif. Terdiri dari dua siklus setiap siklus terdiri dari tiga pertemuan. Subjek pada penelitian ini adalah 21 anak usia 4-5 tahun yang terdiri dari 8 anak perempuan dan 13 anak laki-laki. Teknik pengumpulan data menggunakan observasi, wawancara, tes dan dokumentasi. Validitas data dalam penelitian ini menggunakan triangulasi sumber dan triangulasi metode, sedangkan validitas data kuantitatif menggunakan validitas konstruk. Teknik analisis data yang digunakan adalah analisis interaktif. Hasil penelitian tindakan kelas ini menunjukkan bahwa melalui kegiatan gerak dan lagu anak dapat menyalurkan atau mengekspresikan perasaan dan sikap positif anak melalui nyanyian dan gerakan sehingga melalui kegiatan gerak dan lagu dapat meningkatkan percaya diri anak pada kelompok A TK Aisyiyah 01 Semanggi Pasar Kliwon Surakarta Tahun Ajaran 2016/2017 dari pratindakan sampai siklus II. Hasil ketuntasan percaya diri anak pada pratindakan sejumlah 7 anak dari 21 anak atau sebesar 33\%. Hasil ketuntasan percaya diri anak pada siklus I meningkat menjadi 12 anak atau 57\%. Hasil ketuntasan percaya diri anak pada siklus II menjadi 85\% atau 18 anak. Berdasarkan uraian di atas, hasil penelitian tindakan kelas yang dilaksanakan dalam dua siklus tersebut dapat disimpulkan bahwa dengan penerapan kegiatan gerak dan lagu dapat meningkatkan percaya diri anak kelompok A TK Aisyiyah 01 Semanggi Pasar Kliwon Surakarta Tahun Ajaran 2016/2017. Peningkatan tersebut dibuktikan dengan meningkatnya keberanian anak untuk menyatakan pendapat, bertanya dan menjawab pertanyaan serta anak lebih mandiri dan berani dalam melakukan seuatu, seperti maju kedepan kelas tanpa didampingi guru.
\end{abstract}

Katakunci : percaya diri, gerak dan lagu, anak usia 4-5 tahun

\section{ABSTRACT}

This study aims to improve the confidence of children by applying the songs and movement in the children group A TK Aisyiyah 01 Semanggi Pasar Kliwon Surakarta in the Academic Year 2016/2017. This type of research is classroom action research (PTK) using qualitative and quantitative approaches. Consisting of two cycles each cycle consisting of three meetings. Subjects in this study were 21 children aged 4-5 years consisting of 8 girls 
and 13 boys. Data collection technique used observation, interview, test and documentation. The validity of the data in this study using triangulation and triangulation methods, while the validity of quantitative data using the construct validity. The data analysis technique used is interactive analysis. Results of action research shows that through movement and song the child can channel or express feelings and positive attitudes of children through song and movement so that through movement and song can increase the confidence of children in group A TK Aisyiyah 01 Semanggi Pasar Kliwon Surakarta in the Academic Year 2016/2017 of the pre-action until the second cycle. Results confident mastery of children at pre-action a number of 7 children from 21 children, or by $33 \%$. Results confident mastery of children in the first cycle increased to 12 children, or $57 \%$. Results completeness confident children in the second cycle to $85 \%$ or 18 children. Based on the above, the results of a classroom action research conducted in two cycles can be concluded that with the implementation of movement activities and songs can increase the confidence of children in group A TK Aisyiyah 01 Semanggi Pasar Kliwon Surakarta in the Academic Year 2016/2017. The increase is evidenced by the increasing boldness of children to express their opinions, ask and answer questions and children are more independent and courageous in doing thing else, like to move forward without his class teacher.

Keywords: confident, movement and song, children aged 4-5 years 


\section{PENDAHULUAN}

Usia dini merupakan usia yang tepat untuk mengembangkan aspek-aspek perkembangan, karena usia dini merupakan masa dimana anak memiliki potensi yang sangat besar untuk dapat berkembang pesat. Salah satu aspek perkembangan yang perlu dikembangkan pada anak usia dini adalah aspek perkembangan sosial emosional. Perkembangan sosial emosional pada anak usia dini terdiri dari beberapa aspek, salah satunya adalah perilaku prososial. Menurut Hammond dan Brownell (2015), perilaku prososial merupakan sebuah konsep yang definisinya relatif mudah. Perilaku prososial merupakan sebuah tindakan yang dilakukan secara sukarela dengan tujuan untuk menguntungkan orang lain. Perilaku tersebut dilakukan tanpa memperdulikan perbedaan-perbedaan yang ada diantara mereka, seperti perbedaan jenis kelamin, ras, budaya, agama, maupun perbedaan yang lainnya.

Perilaku prososial menjadi salah satu perilaku yang penting untuk dikembang sejak anak masih berusia dini. Hal ini sesuai dengan pendapat Knafo-Noam (2016) yang menyatakan bahwa perilaku
KUMARA CENDEKIA Vol. 7 No. 3 September 2019 prososial memang penting untuk dikembangkan pada anak sejak masih berusia dini, karena

perilaku

$$
\text { prososial }
$$

akan

berpengaruh terhadap

kemampuan anak dalam

bersosialisasi dan mengelola emosi ketika berhubungan dengan orang lain. Anak yang sudah terbiasa berperilaku prososial sejak usia dini akan lebih mudah bersosialisasi dan berinteraksi dengan orang lain ketika anak berada dilingkungan yang baru. Selain itu, perilaku prososial juga berhubungan dengan prestasi akademik anak, dan

pengembangan kompetensi kognitif, seperti kemampuan anak untuk memecahkan masalah dan kemampuan dalam memahami nilai-nilai moral yang ada dilingkungannya. Dewasa ini, seiring dengan perkembangan zaman dan media teknologi yang semakin maju, perilaku prososial mulai luntur dan menurun. Hal ini ditandai dengan semakin tinginya sikap individualis pada anak-anak, sehingga menyebabkan mereka sulit menjalin pertemanan atau hubungan baik dengan orang lain (Palmer, 2014). Saat ini anak-anak cenderung lebih senang 
melakukan sesuatu secara sendiri atau individual dari pada dengan orang lain. Sementara itu, Kinanti (2015) juga menjelaskan bahwa

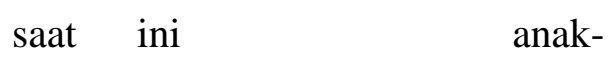

anak jarang bermain bersama dengan temannya, seperti bermain sepak bola atau sekedar bermain diluar

rumah.

Anak- cenderung lebih senang menghabiskan waktunya didalam rumah dengan bermain gadged. Meres dan Kretz (2015) juga menyatakan bahwa saat ini perilaku prososial seperti membantu pada anak-anak mulai menurun dan justru perilaku-perilaku anti sosial seperti perilaku agresif meningkat pada anak-anak.

Hal tersebut sesuai dengan hasil wawancara kepada beberapa guru PAUD didaerah Surakarta yang menyatakan bahwa saat ini perilaku prososial pada anak usia dini ketika di sekolah menurun. Ketika di sekolah anak kurang memiliki kepedulian kepada temannya seperti ketika ada teman yang menangis banyak anak hanya melihat saja dan tidak menenangkannya, begitu juga ketika ada anak yang bertengkar hanya sebagian anak yang mau melerai dan melapor pada guru. Saat bergantian menggunakan sesuatu atau melakukan sesuatu di sekolah, banyak anak
KUMARA CENDEKIA Vol. 7 No. 3 September 2019 yang berebutan mendahului dan enggan untuk antri bergiliran dengan temannya. Selain itu, kemurahan hati anak dalam berbagi juga menurun, banyak anak enggan berbagi peralatan sekolah atau mainan sekolah dengan temannya. Begitupun ketika berbagi makanan atau minuman, sebagian anak juga enggan membaginya dengan teman lain.

Menurunnya perilaku prososial pada anak usia dini tentu dipengaruhi oleh beberapa faktor. Prot, dkk. (2014) menjelaskan bahwa salah satu faktor yang mempengaruhi perilaku prososial anak adalah media teknologi. Penggunaan media teknologi untuk anak yang berisi kontenkonten prososial dapat menyebabkan peningkatan jangka panjang sifat empati dan perilaku membantu pada anak. Selain faktor media teknologi, juga terdapat faktor lainnya seperti faktor kematangan usia anak. kematangan kognitif anak, dan pola asuh orang tua (Beaty, 2013), faktor budaya dan jenis kelamin (Hammon, dkk., 2015), faktor teman sejawat atau peer group (Burt \& Klump, 2014), dan faktor sosial ekonomi orang keluarga (Piff \& Robinson, 2017).

Menurut hasil penelitian yang dilakukan oleh Chen, Zhu, dan Chen (2013) bahwa anak-anak dari keluarga sosial ekonomi yang berpendapatan rendah 
memang memiliki perilaku sosial yang lebih tinggi, seperi menyumbangkan lebih banyak stiker ketika melakukan permaianan daripada anak-anak dari keluarga dengan pendapatan tinggi. Sementara itu, Bobbitt dan Gershoff (2016) menjelaskan bahwa anak-anak usia prasekolah yang berasal dari keluarga dengan pendapatan ekonomi yang

rendah justru memiliki perilaku sosial emosional yang sedikit lebih kacau.

Berdasarkan urain di atas, ada beberapa faktor yang mempengaruhi perilaku prosososial anak, salah satunya faktor pendapatan orang tua. Penelitian ini dilakukan untuk mengetahui apakah pendapatan orang tua memiliki hubungan dengan perilaku prososial anak usia dini yang berumur 5-6 tahun selama disekolah.

\section{Perilaku Prososial Anak}

Perilaku prososial merupakan bagian dari aspek perkembangan sosial emosional. Perilaku prososial merupakan sebuah tindakan yang dilakukan dengan cara yang menguntungkan orang lain (De Backer, dkk., 2015). Sementara itu, Toseeb (2017) menjelaskan bahwa perilaku prososial melibatkan perilaku yang responsif secara positif terhadap kebutuhan dan
KUMARA CENDEKIA Vol. 7 No. 3 September 2019 kesejahteraan orang lain.

Perilaku prososial yang berkembang pada anak terdiri dari beberapa aspek. Beaty (2013) menjelaskan bahwa perilaku prososial pada anak usia dini terdiri dari baspek empati, kedermawanan atau kemuraan hati, kerja sama dan kepedulian. Empati merupakan kemampuan merasakan seperti yang dirasakan orang lain. Empati pada anak usia dini seperti mengetahui perasaan anak lain dan menunjukkan kepedulian kepada temannya yang mengalami kesusahan (sedih atau menangis) dengan datang menghampiri, berbicara kepadanya, menyentuhnya atau menghiburnya. Kemurahan hati merupakan perilaku berbagi dengan orang lain dan memberikan sesuatu kepada orang lain. Kerja sama merupakan perilaku bergantian secara sukarela atau memenuhi permintaan dengan riang. Kepedulian merupakan perilaku seperti membantu oranglain mengerjakan tugas serta membantu orang lain yang membutuhkan bantuan.

Perkembangan perilaku prososial pada anak berkembang seiring dengan perkembangan usia dan perkembangan kognitif anak. Hammond, dkk. (2017) menjelaskan bahwa perilaku prososial muncul dan ditemukan sejak tahun awal kehidupan. Perilaku prososial yang muncul 
KUMARA CENDEKIA Vol. 7 No. 3 September 2019

pada tahun pertama kehidupan anak seperti perilaku membantu orang tua pada konteks merawat dirinya dan menyelesaikan beberapa tugas rumah yang sederhana. Pada usia 4 bulan anak mulai

sehingga bisa memakaikan sepatunya, pada usia 14 bulan membantu mengambilkan pakaian dari lantai dan meletakkannya pada keranjang, dan pada usia 16 bulan mulai membantu mencuci pakaian dengan menutup pintu mesin cuci dan menyalakannya.

Menurut Beaty (2013) pada usia sekitar 18 bulan anak mulai berperilaku prososial dengan menunjukkan perhatiannya kepada orang lain, seperti dengan menyerahkan boneka miliknya kepada saudara mereka yang sedang menangis. Pada usia 2 hingga 6 tahun anak sudah mulai bereaksi dan merespon orang yang ada disekitarnya. Hal ini tampak ketika anak usia 2 atau 3 tahun mulai menyadari bahwa perasaan orang lain mungkin terkadang berbeda dengan perasaannya serta anak sudah mampu membedakan ekspresi-ekspresi wajah orang lain. Saat anak berusia 3 tahun anak juga mulai memberikan bantuan kepada orang lain yang membutuhkan bantuannya. membantu orang tua membalutnya, hanya dengan membimbing anggota tubuhnya kepakaian, pada usia 10 bulan mengeluarkan kakinya

\section{Pendapatan Orang Tua}

Pendapatan merupakan hal yang menarik dan sering dibicarakan dalam masyarakat. Gilarso (2004) menjelaskan bahwa pendapatan adalah arus masuk 
berupa upah, bunga, sewa, dan laba serta arus masuk lainnya yang diterima oleh masyarakat sebagai balas karya atas sumbangannya dalam proses produksi. Terdapat beberapa bentuk pendapatan yang biasa diterima oleh masyarakat. Badan Pusat Statistik (BPS) Indonesia menjelaskan bahwa pendapatan yang diterima dapat berbentuk uang maupun berbentuk barang. Pendapatan yang berbentuk uang meliputi upah dan gaji atas jam kerja atau pekerjaan yang telah diselesaikan, upah lembur, semua bonus dan tunjangan, perhitungan waktu-waktu tidak bekerja, bonus yang dibayarkan tidak teratur, penghargaan, dan nilai pembayaran sejenisnya. Sementara itu untuk pendapatan yang berbentuk barang dinilai dengan harga setempat.

Pendapatan yang diterima seseorang dapat berasal dari beberapa sumber. Gilarso (2004) menjelaskan bahwa pendapatan berasal dari beberapa sumber seperti bersumber dari usaha sendiri melalui berdagang atau berwiraswasta, bekerja pada orang lain sebagai karyawan atau pegawai dan bersumber dari kepemilikan sendiri seperti dari kepemilikan kebun, sawah, atau rumah yang disewakan. Sementara itu Wang dan Shen (2014) menyatakan bahwa
KUMARA CENDEKIA Vol. 7 No. 3 September 2019 pendapatan dapat bersumber dari pemegangan saham, usaha kemitraan, upah sebagai pekerja, berwiraswasta, dan penyewaan.

Tinggi rendahnya pendapatan yang diterima seseorang dipengaruhi oleh beberapa faktor. Noor (2007) menjelaskan bahwa peningkatan pendapatan dipengaruhi oleh faktor seperti lapangan pekerjaan. Tersedianya berbagai lapangan pekerjaan memungkinkan masyarakat untuk memiliki pekerjaan yang lebih beragam dan dapat meningkatkan pendapatannya. Semakin tinggi posisi pekerjaan atau semakin baik tempat bekerja maka pendapatan yang diterima juga akan semakin tinggi. Jagielski, dkk. (2017) menjelaskan bahwa pendapatan seseorang dipengaruhi oleh pendidikan. Orang yang memiliki pendidikan tinggi akan bekerja pada posisi yang tinggi sehingga pendapatannya juga tinggi. Selain pendidikan, pendapatan juga di pengaruhi oleh ketrampilan. Orang yang terampil dan memiliki ketrampilan tertentu memiliki produktivitas yang lebih tinggi dalam bekerja sehingga dapat meningkatkan pendapatannya. 


\section{METODE}

Penelitian ini merupakan penelitian dengan pendekatan kuantitatif jenis korelasi yang dilaksanakan selama 6 bulan, mulai bulan Maret hingga bulan Agustus 2017. Populasi penelitian ini adalah 132 anak berusia 5-6 tahun yang bersekolah di Gugus

8 Jasmine Laweyan Surakarta. Sampel penelitian adalah 99 anak yang diambil menggunakan teknik simple random sampling dengan rumus Slovin. Teknik pengumpulan data dalam penelitian ini menggunakan kuesioner

Kuesioner dalam penelitian ini ada dua jenis. Kuesioner yang pertama, yaitu kuesioner yang diberikan kepada orang tua untuk mengetahui pendapatan orang tua setiap bulannya. Kuesioner pendapatan ini diisi oleh orang tua dengan menulis nominal pendapatan orang tua yang diterima setiap bulannya

Kuesioner yang kedua, yaitu kuesioner yang diberikan kepada guru kelas untuk mengetahui perkembangan perilaku prososial anak yang berusia 5-6 tahun selama di sekolah. Kuisioner yang diberikan kepada guru kelas diisi menggunakan skala Likert dengan behavioral cheklist untuk pengisiannya.

Uji validitas instrumen perilaku
KUMARA CENDEKIA Vol. 7 No. 3 September 2019 prososial anak terdiri dari beberapa tahap. Tahap pertama, mengkonsultasikan instrumen pada ahli dibidangnya (expert judgment), setelah instrumen dinyatakan valid oleh expert judgment, tahap selanjutnya melakukan uji coba instrumen. Data yang diperoleh dari hasil uji coba kemudian diuji validitas instrumen menggunakan Corected Item-Total

Correlation dan diuji reliabilitas menggunakan Cronbach's Alpha dengan bantuan SPSS for windows. Sementara itu, teknik analisis data uji hipotesis menggunakan uji korelasi Spearman rho 
dengan bantuan SPSS untuk mengetahui seberapa besar hubungan antara pendapatan orang tua terhadap perilaku
KUMARA CENDEKIA Vol. 7 No. 3 September 2019 prososial anak usia 5-6 tahun selama di sekolah.

\section{HASIL DAN PEMBAHASAN}

Uji hipotesisi penelitian ini dilakukan hipotesisi korelasi Spearman rho dengan uji korelasi Spearman rho dengan bantuan SPSS. Berikut ini hasil uji menggunakan bantuan SPSS :

Tabel 1. Hasil Uji Hipotesis Korelasi Spearman rho

\begin{tabular}{cccrr}
\hline $\begin{array}{c}\text { Spearman's } \\
\text { rho }\end{array}$ & Pendapatan & Correlation & 1,000 &,$- 501^{* *}$ \\
& & Coefficient & & \\
& & Sig.(2-tailed) & &, 000 \\
& Prososial & N & 99 & 99 \\
& & Correlation &,$- 501^{* *}$ & 1,000 \\
& & Coefficient & & \\
& & Sig.(2-tailed) &, 000 & \\
& & $\mathrm{~N}$ & 99 & 99 \\
\hline
\end{tabular}

** Correlation is significant at the 0.01 level (2-tailed).

Berdasarkan hasil uji hipotesis 99 dan taraf signifikansi yang dipakai menggunakan Spearman rho diatas dapat adalah 5\% $(0,05)$ untuk uji dua pihak, dilihat bahwa nila koefisien korelasi sehingga didapat $r_{\text {tabel }}$ sebesar 0,198 . Oleh Spearman rho antara variabel sebesar 0,501 . Selanjutnya dengan jumlah sampel karena $r_{\text {hitung }}$ 0,501 lebih besar dari $r_{\text {tabel }}$ 0,197 menunjukkan bahwa $\mathrm{H}_{0}$ ditolak dan 
$\mathrm{H}_{1}$ diterima dan terdapat hubungan antara kedua variabel. Hasil dari koefisien korelasi 0,501 menunjukkan

kategori hubungan antar variabel penelitian berada pada tingkat sedang/cukup.Sementara itu koefisien korelasi menunjukkan

tanda negatif (-) yang berarti arah korelasinya adalah dua arah atau berlawanan, sehingga ketika pendapatan orang tua tinggi maka perilaku

prososial anak rendah dan sebaliknya ketika pendapatan orang tua rendah maka perilaku prososial anak tinggi. Hasil penelitian ini juga mendukung penelitian yang dilakukan oleh Piff dan Robinson (2017) yang menyatakan bahwa anak yang berasal dari kelas sosial yang rendah memiliki perhatian yang lebih tingi kepada orang lain dan memiliki kepekaan yang lebih besar terhadap kesejahteraan orang lain dibandingkan dengan anak yang berasal dari kelas sosial yang tinggi. Anak yang berasal dari kelas sosial yang tinggi menunjukkan pola kognisi sosial yang lebih

berorientasi pada diri sendiri.

Hasil penelitian Chen, Zhu, dan Chen (2013) juga membuktikan bahwa anakanak dari keluarga berpenghasilan rendah memiliki perilaku prososial yang lebih baik, seperi menyumbangkan lebih banyak stiker ketika melakukan permaianan daripada

anak-anak dari keluarga berpenghasilan tinggi. Justice, dkk. (2017) juga menjelaskan bahwa anak usia dini yang berasal dari keluarga yang berpendapatan rendah memiliki kesiapan perilaku sosial yang lebih baik ketika masuk sekolah taman kanak-kanak. Sebaliknya anak usia dini yang berasal dari keluarga yang berpendapatan tinggi memiliki kesiapan perilaku prososial yang rendah ketika. Park dan Zhan (2017) juga menyatakan bahwa anak-anak dari keluarga berpendapatan rendah memiliki perilaku sosial yang lebih tinggi dan lebih sedikit menimbulkan masalah, hal ini karena anak dari orang tua dengan pendapatan rendah dirawat sendiri dengan baik oleh orang tuanya.

\section{SIMPULAN DAN SARAN}

Berdasarkan hasil uji hipotesis penelitian, dapat disimpulkan bahwa pendapatan orang tua berpengaruh terhadap perilaku prososial anak usia 5-6 tahun selama disekolah. yang berarti arah korelasi berlawanan atau dua arah, sehingga ketika pendapatan orang tua tinggi maka perilaku prososial pada anak rendah, dan sebaliknya 
ketika pendapatan orang tua rendah maka perilaku prososial pada anak tinggi

Hasil penelitian ini diharapkan dapat menambah pengetahun pihak orang tua dan pihak sekolah tentang bagaimana perkembangan perilaku prososial anak usia 5-6 tahun selama di sekolah, mengetahui faktor-faktor yang dapat mempengaruhi perkembangan perilaku prososial anak, dan pentingnya mengembangkan perilaku prososial sejak anak usia dini. Hasil penelitian ini juga dapat dijadikan pedoman atau acuan bagi peneliti selanjutnya yang akan melakukan penelitian sejenis, atau menganalisis lebih detail tentang hubungan kedua variabel penelitian ini. Akan tetapi peneliti lainnya sebaiknya menggunakan banyak variasi variabel seperti jenis kelamin, pola asuh orang tua, sosial budaya atau variasi lainnya agar tingkat keakuratannya hubungannya lebih tinggi.

\section{DAFTAR PUSTAKA}

Departemen Pendidikan dan Kebudayaan (2014). Peraturan Menteri Pendidikan dan Kebudayaan Republik Indonesia Nomor 146 Tahun 2014. (2015). Kurikulum 2013 Pendidikan Anak Usia Dini. Jakarta: Permendikbud.

Departemen Pendidikan Nasional. Peraturan Menteri Pendidikan Nasional tentang
KUMARA CENDEKIA Vol. 7 No. 3 September 2019 Standar Pendidikan Anak Usia Dini. (2009). Kementrian Pendidikan Nasional. Direktorat Pendidikan Anak Usia Dini Pendidikan Nonformal dan Informal.

Delfita, R. Meningkatkan Kemampuan Berbahasa Anak Melalui Permainan Gambar dalam Bak Pasir di Taman Kanak-Kanak Bina Anaprasa Mekar Sari Padang. Jurnal Pesona PAUD.

Devi, S. (2015). Budaya Literasi Indonesia Peringkat Ke 2 Terburuk. Diakses pada 3 Februari 2016 dari http://blog.danadidik.com/budaya-literasiindonesia- peringkat-ke-2-terburuk/.

Diamond, K; Gerde, H; Powell, D (2008). Development in Early Literacy Skills During The Pre-kindergarten Year in Head Start: Relations Between Growth in Children's Writing and Understanding of Letters. Early Childhood Research Quarterly, 467478.

Dunst, C. et all. (2006). Framework for Developing Evidence-Based Early Literacy Learning Practices. CELLpapers. 
KUMARA CENDEKIA Vol. 7 No. 3 September 2019

Fridin, M. (2014). Storytelling By a Neolaka, A. (2014). Metode Penelitian dan Kindergarten Social Assistive Robot: Statiska. Bandung: Rosda.

A Tool for Constructive Learning in Preschool Education. Computers \& Education , 53-64.

Jones, C. Clark, S. Reutzel, D (2013). Enhancing Alphabet Knowledge Instruction: Research Implications and Practical Strategies for Early Childhood Educators. Early Childhood Educ J , 81-89.

Suarti, N. K. A (2014). Bermain Konstruktif Sambil Belajar Konsep Bilangan pada Anak Usia 5-6 Tahun. Jurnal Paedagogy.

Sugiyono. (2012). Metode Penelitian Pendidikan Pendekatan Kuantitatif, Kualitatif, dan $R$ \& D. Bandung: Alfabeta.

Suyono \& Hariyanto. (2011). Belajar dan Pembelajaran. Bandung: Rosda. 
KUMARA CENDEKIA Vol. 7 No. 3 September 2019 